\title{
Social Media in the Marketing of Higher Education Institutions in Poland: Preliminary Empirical Studies
}

\author{
Grzegorz Mazurek, Paweł Korzyński, Anna Górska
}

\begin{abstract}
A B S T R A C T
Objective: To investigate how higher education institutions (HEIs) in Poland take advantage of social media marketing activities. In particular, the work considers managerial and promotional implications of social media usage along with the barriers to implementing such activities in HEls in Poland.

Research Design \& Methods: The empirical research was carried out in the period of April-June 2017 on a sample of $90 \mathrm{HEls}$ in Poland, using an online questionnaire and individual invitations sent out to marketing departments of these institutions. $50 \mathrm{com}$ pletely filled-out surveys were used to compile the results.
\end{abstract}

Findings: Social media are considered to be 'youth' media expressed in the target audience and content of the message. SM are not used for promoting research and academia. Researchers and Administration are perceived as stakeholders not understanding the potential of SM for building school's image and reputation. Universities in Poland operate with little support from external entities.

Implications \& Recommendations: The article provides information how to grasp the dynamics of the development of the utilisation of social media by Polish HEls. Juxtaposition of the findings with the results obtained from research conducted on students and academic staff members along with the comparison of the results with the research executed on different markets would shed a new light on the social media usage in HEls.

Contribution \& Value Added: It is the first study where social media marketing activities and strategies are analysed in the HEI sector in Poland. Social media are a significant communication channel for HEls, determining the changes in the way the $\mathrm{HEls}$ interact with their stakeholders.

$\begin{array}{ll}\text { Article type: } & \text { research article } \\ \text { Keywords: } & \text { social media; marketing; higher education institutions }\end{array}$

JEL codes: $\quad$ M31, O32

Received: 16 August $2018 \quad$ Revised: 8 November $2018 \quad$ Accepted: 1 December 2018

\section{Suggested citation:}

Mazurek, G., Korzyński, P., \& Górska, A. (2019). Social Media in the Marketing of Higher Education Institutions in Poland: Preliminary Empirical Studies. Entrepreneurial Business and Economics Review, 7(1), 117-133. https://doi.org/10.15678/EBER.2019.070107 


\section{INTRODUCTION}

Social media are usually defined as 'a group of Internet-based applications that build on the ideological and technological foundations of Web 2.0, and that allow the creation and exchange of user-generated content as well as interactive discussion' (Kaplan \& Mazurek, 2018, p. 275).

Social media are composed of Web 2.0 and web-based applications that enable a twoway communication involving sharing certain specific content, i.e. photos, videos, opinions, and comments (Kaplan \& Haenlein, 2010, p. 61). Thanks to social media, their users are able to share their emotions, experiences, opinions, and remarks (Mazurek, 2008; Skulme \& Praude, 2016). Blackshaw and Nazzaro (2004), highlighting the role of social media in marketing practice, define them as diverse sources of online information, where the information itself is created, initiated, circulated and used by consumers for the purpose of educating each other about products, brands, services, personalities and issues.

Social media differ significantly from the so-called traditional media (Chaffey \& Ellis-Chadwick, 2012; Heinze, Fletcher, \& Rashid, 2016). First, they are interactive, which somewhat forces a dialogue between their users with the simultaneous levelling-out of the hierarchy among them. This is what e.g. Himelboim, Golan, Moon and Suto (2014, p. 366) stress by claiming that the potential of social media is about their ability to facilitate the formation of relationships because they can make communication reciprocal, interactive, symmetrical, and dialogue-based. By taking advantage of social media, organisations can learn more about the needs of their stakeholders, develop the relations established with them, increase the level of engagement, and endorse and promote their brands (Mazurek, 2018).

The use of social media in organisations takes on three levels (Mazurek, 2018, p. 18):

- operational level - whose essence is using social media to pursue objectives related to brand promotion, image building, ongoing customer service, entering into and maintaining a dialogue between the organisation and the social media users;

- tactical level - which is about using social media and messages promoted via social media in order to generate conversions, i.e. to convert Internet (social media) users into customers who will be effectively encouraged to make a particular transaction based on the content they have been provided with (Macik, Mazurek, \& Macik, 2012, p. 39);

- strategic level - which is essentially about using social media to change the way in which a given organisation functions - to make it networked, of undefined borders, creating value taking advantage of network approach and user engagement (Mazurek, 2014, p. 75). In this approach, social media should not be considered from the point of view of the function of marketing (plans, activities, projects) but from the perspective of a whole organisation, and one of the fundamental phenomena within this level is the emergence of virtual communities (Mazurek, 2008; Bartosik-Purgat, 2018).

Building a virtual community around the brand of a $\mathrm{HEI}$ and providing such a community with the right conditions to exchange experience or opinions regarding the institution translates into a high level of engagement of the involved stakeholders (students, employees, applicants, etc.) and bears fruit in the form of values created in a network of relationships (Nevzat, Amca, Tanova, \& Amca, 2016, p. 555; Zickar, Ron, \& Arnold, 2018; Lazányi et al., 2017). Nowadays, developing a strong and solid community is necessary not only to 
attract new students but also to communicate with graduates and other stakeholders of a given school or university (McAlexander, Koenig, \& Schouten, 2006, p. 114; Zickar, Ron, \& Arnold, 2018). As HEls are operating in the increasingly competitive environment (Sułkowski, 2016), the use of new communication channels by HEls seems to be justified.

In order to find out how Polish HEI utilise social media tools for marketing purposes and communicating with their stakeholders, we conducted a quantitative study, based on the sample of 90 institutions in Poland. Surveys were sent to marketing departments of HEls directly.

The article is divided into five sections, in the second section we present the literature review concerning the use of social media in the context of HEls as well as its role in students' enrolment and in the process of studying. The third section is to present the methods of data inquiry, in the fourth one we present the results. Finally, the fifth section is dedicated to the concluding remarks.

\section{LITERATURE REVIEW}

\section{Social Media and Higher Education Institutions}

Today's social media are tools that offer an amazing potential, one that schools and universities are well aware of trying to take advantage of contemporary means of communication for promotion, enrolment, or education related purposes. HEls have joined the ranks of organisations making regular use of innovative communication channels, featuring social media in their marketing strategies (Constantinides, Zinck, \& Stagno, 2010 , p. 10). Studies into social media prove that HEls are increasingly more proficient in utilising the information appearing on various social media platforms with a view to making their offers more attractive, improving their image or taking care about the relations with their clients (Pharr, 2016, p. 11).

It is important to notice that today's market of higher education at the undergraduate and graduate level is dominated by a generation of the so-called digital natives - young people who treat the Internet as a natural element of their everyday life, a world where they spend hours on a daily basis (Jones, Ramanau, Cross, \& Healing, 2010, p. 726). This target group is over 'one third of working adults', expecting online authenticity and transparency of brands making their online presence, with emotions and experiences being at the top of their list (Smilansky, 2017, p. 19). Studies also prove that contemporary students find it more convenient to use social media to stay in touch with their schools and universities (Rutter, Roper, \& Lettice, 2016, p. 3099; Kajanová et al., 2017).

Press adverts, fairs, distributed leaflets and brochures, or popular web-based activities such as online advertising, website, or e-mailing campaigns are all examples of activities in the field of marketing communication - all pursued on a wide scale in the area of higher education. The development of the digital era accompanied by the changing habits and behaviours of Internet users has considerably limited the significance and effectiveness of the use of some of the abovementioned tools, which have been gradually replaced by more innovative ways to reach Generation Y. This generation, as studies show, not only prefers a more digital interaction with brands but also considers opinions and direct contact through social media more credible and valuable than the interaction based on traditional marketing solutions (Kelleher \& Sweetser, 2012, p. 109; Janoskova \& Kliestikova, 2018). 
By adapting social media, universities are able to reach an audience that the traditional media may simply fail to get through to - especially in the case of a younger audience. What is more, interactive tools of online communication may also encourage representatives of other stakeholder groups, e.g. new academics and graduates to get in touch with a given education institution (Carver, 2014, p. 1).

The range of social media available to HEls is highly diversified (Mazurek, 2014, p. 29; Mazurek, 2018). The social media taken advantage of by schools and universities include:

- social networking services (e.g. Facebook);

- online video-publishing/viewing/sharing services (e.g. YouTube);

- photo social networking services (e.g. Instagram, Pinterest, Flickr);

- services/applications designed for online publishing and short-time viewing of video content (e.g. Snapchat);

- blogging/microblogging services (e.g. Twitter);

- professional-business networking services (e.g. LinkedIn);

- online Internet forums (message boards) and discussion groups.

Each of the above may be used in communication with different groups of stakeholders. Also, the published content differs depending on the social media in use (see study findings presented further). The selection of a given social media platform depends also on the management aspect - managing each such platform requires both certain specific content and time, including time to interact with the users of a given platform. The available content, the selection of the platform according to a given target group, and the sphere of management at a given education institution are all factors crucial to the choice of the social media to be used in the intended communication activities.

Examples of operational utilisation of different social media platforms are shown in the Table 1.

\section{Social Media and Students Enrolment}

Social media are especially important tools in the context of enrolment activities in the higher education sector (Constantinides \& Zinck Stagno, 2011, p. 18). From the point of view of a school/university, social media may make enrolment activities become more friendly and personalised thanks to the possibility of instant interaction with various groups of stakeholders - parents of applicants, current students, representatives of business partners working with the school/university, etc. Many higher education admissions experts confirm that communication through social media plays a particular part at the stage of enrolment because the applicants' experience in contacting the institution they have selected becomes more personalised, which is, in turn, of great significance in the times of intensified competition (Noel-Levitz, 2014). It is also reasonable to mention studies by Wilson (2013), according to which admissions offices of HEls take advantage of social media mainly to get reach potential candidates in an environment where they feel best (Wilson, 2013, p. 53). The rate of penetration of social media is exceptionally high among potential students, who qualify as the aforesaid digital natives. These are people who are highly technologically literate, 'immersed' in social media. According to the young generation of digital natives, social media profiles (e.g. Facebook fanpage) can give you a better idea of the student life at a given school or university, i.e. about the academic culture, atmosphere, attractions, etc. than other sources of information, which helps 
them make a better choice of the place where they are going to study and grow over the next few years (Constantinides \& Zinck Stagno, 2011, p. 21).

Table 1. Examples of the Use of Social Media in the Higher Education Sector

\begin{tabular}{|c|c|c|c|}
\hline Social media type & $\begin{array}{l}\text { Example of } \\
\text { the plat- } \\
\text { form/service }\end{array}$ & Examples of activities & $\begin{array}{l}\text { Target } \\
\text { group }\end{array}$ \\
\hline $\begin{array}{l}\text { Social networking } \\
\text { services }\end{array}$ & Facebook & $\begin{array}{l}\text { Publishing news, recent events, and achievements } \\
\text { of the school/university, students; Publishing in- } \\
\text { teresting findings of scientific research; Publishing } \\
\text { information about the offered programmes. }\end{array}$ & $\begin{array}{l}\text { Appli- } \\
\text { cants, Stu- } \\
\text { dents, } \\
\text { Media }\end{array}$ \\
\hline $\begin{array}{l}\text { Online video-publish- } \\
\text { ing/viewing/sharing } \\
\text { services }\end{array}$ & YouTube & $\begin{array}{l}\text { Publishing interviews with outstanding professors, } \\
\text { experts; Presentation of student profiles, scientific } \\
\text { clubs; Video records of major events organised at } \\
\text { the school/university. }\end{array}$ & $\begin{array}{l}\text { Appli- } \\
\text { cants, } \\
\text { Business }\end{array}$ \\
\hline $\begin{array}{l}\text { Photo social net- } \\
\text { working services }\end{array}$ & $\begin{array}{l}\text { Instagram, } \\
\text { Pinterest, } \\
\text { Flickr }\end{array}$ & $\begin{array}{l}\text { Presentation of major events taking place at the } \\
\text { school/university }\end{array}$ & $\begin{array}{c}\text { Applicants, } \\
\text { Students, } \\
\text { Media } \\
\end{array}$ \\
\hline $\begin{array}{l}\text { Services/applications } \\
\text { designed for online } \\
\text { publishing and short- } \\
\text { time viewing of video } \\
\text { content }\end{array}$ & Snapchat & $\begin{array}{l}\text { Presentation of interesting events taking place at } \\
\text { the school/university, student projects, scientific } \\
\text { clubs, student groups }\end{array}$ & $\begin{array}{l}\text { Appli- } \\
\text { cants, Stu- } \\
\text { dents }\end{array}$ \\
\hline $\begin{array}{l}\text { Blogging/microblog- } \\
\text { ging services }\end{array}$ & Twitter & $\begin{array}{l}\text { Information about major events and achieve- } \\
\text { ments }\end{array}$ & Media \\
\hline $\begin{array}{l}\text { Professional business } \\
\text { networking services }\end{array}$ & Linkedln & $\begin{array}{l}\text { Presentation of research findings and results, in- } \\
\text { terviews with professors }\end{array}$ & $\begin{array}{l}\text { Graduates, } \\
\text { Students, } \\
\text { Business }\end{array}$ \\
\hline $\begin{array}{l}\text { Discussion forums, } \\
\text { online communities }\end{array}$ & $\begin{array}{l}\text { Google } \\
\text { Groups }\end{array}$ & $\begin{array}{l}\text { Answers to applicant inquiries, monitoring of con- } \\
\text { tent - signals coming from people interacting with } \\
\text { the school/university. }\end{array}$ & Applicants \\
\hline
\end{tabular}

Source: own study.

The quoted studies somewhat prove by the way that from the point of view of an applicant, the selection of the school/university is not made based only on the education offer but also on the broadly defined value offered by e.g. scientific clubs, particular teachers, other students, graduates, and even the overall atmosphere or the social or sports activities pursued by or at a given institution. These additional values can surely be communicated through social media.

Regardless of the type of the social platforms in use, potential students expect personalised communication and authenticity, which lets them decide if a given school/university is the right place for them. To conclude, the increasing role of social media as the solutions applicants to HEls choose most often to find information about the schools/universities they consider should not come as a surprise (Constantinides \& Zinck Stagno, 2011, p. 21).

\section{Social Media in the Process of Studying}

Students who use social media in their everyday life see a clear difference in using them for learning-related purposes and for non-learning-related purposes (Jones \& Czerniewicz, 
2010, p. 319). In the former case, social media are present and utilised to a limited extent, which leads to a so-called digital dissonance. Their natural way of communication should be therefore embraced in and made part of the forms of communication used in practice by $\mathrm{HEls}$. The necessity for HEls to adapt in the area of communicating with students is proven by studies carried out by e.g. Hrastinski and Aghaee (2012), according to whom students name social media, next to direct contact and knowledge management platforms, as the most important channels of the whole process of teaching and their functioning at their school/university (the so-called 'educational experience') (Hrastinski \& Aghaee, 2012, p. 455). According to studies by Caraher and Braselman (2010), students use social media to communicate with other students, to work, and to communicate with their teachers (Caraher \& Braselman, 2010). Moreover, taking advantage of social media as tools to encourage students to engage more actively in the academic life of their school/university may have positive effects and thus help schools/universities achieve the set objectives (Bennet \& Maton, 2010, p. 329; Dumford \& Miller, 2018). The utility of social media for higher education is therefore significant, especially in the scope of marketing communications targeted at the main groups of stakeholders of education institutions - applicants and students.

So far, there have been no extensive studies carried out in Poland to investigate this issue. The author focused in his study especially on the following matters:

- the scope and the aim of the utilisation of particular types of social media;

- the way communication in social media is managed;

- the barriers to a broader adoption of social media among HEls in Poland;

- the attitudes of respondents - representatives of HEls - to social media activity.

Therefore, our main research objective was to showcase how and why institutions of higher education utilise social media.

\section{MATERIAL AND METHODS}

The research was carried out in the period of April-June 2017 on a sample of $90 \mathrm{HEls}$ in Poland, using an online questionnaire and by means of individual invitations sent out to marketing/PR departments of these institutions - and to people representing these departments. The sample included all public HEls listed as academic institutions of higher education and 20 best non-public HEls, selected on the basis of the 2017 'Perspektywy' ranking. The decision not to include all non-public HEls in Poland in the studies (261 institutions as of 07.06.2017) was made based on the assumption of potential overrepresentation of this group compared to its disproportionately lower impact on the sector of higher education in Poland, because of no social media profiles in the case of many of them, or because of an unclear status of some of them (e.g. 'in liquidation'). The invitations were sent to representatives of $90 \mathrm{HEls}$, the survey was filled by 55 persons as presented below. 50 completely filled-out surveys were used to compile the results, which made it possible to arrive at a high rate of return, close to $56 \%$. Respondents were people employed in the marketing department on the following positions:

- strategic positions (decision-making in the area of budget matters, course of action) $-22 \%$ of the respondents;

- management positions (budget implementation, team management) $-32 \%$ of the respondents; 
- specialist positions (project implementation) - 38\% of the respondents;

- assistant positions (support activities) - $8 \%$ of the respondents.

Table 2. Distribution of Heis Based on Type

\begin{tabular}{|c|c|c|c|}
\hline Type of education institution & $\begin{array}{c}\text { Number of } \\
\text { education } \\
\text { institutions }\end{array}$ & $\begin{array}{c}\text { Number in- } \\
\text { cluded in the } \\
\text { research }\end{array}$ & $\begin{array}{l}\text { Percentage-based } \\
\text { representativeness } \\
\text { of a given HEI type }\end{array}$ \\
\hline Universities & 18 & 14 & $78 \%$ \\
\hline Technical education institutions & 19 & 7 & $37 \%$ \\
\hline Economic education institutions & 6 & 5 & $83 \%$ \\
\hline Teacher education institutions & 6 & 3 & $50 \%$ \\
\hline Agricultural/natural science education institutions & 6 & 3 & $50 \%$ \\
\hline Institutions of physical education & 6 & 3 & $50 \%$ \\
\hline Medical education institutions & 9 & 8 & $89 \%$ \\
\hline Non-public institutions of higher education & 20 & 6 & $30 \%$ \\
\hline Overall & $\begin{array}{c}90 \text { institu- } \\
\text { tions }\end{array}$ & $\begin{array}{c}50 \text { institu- } \\
\text { tions }\end{array}$ & $56 \%$ \\
\hline
\end{tabular}

Source: own study.

\section{RESULTS AND DISCUSSION}

\section{Management of Social Media at Polish Higher Education Institutions}

The vast majority of HEls ( 45 out of 50 surveyed) have been taking advantage of social media for at least three years, with 20 of them ( $40 \%$ of the whole surveyed sample) using social media for over six years. Only three of them admitted to have been using social media for just two years.

The way social media are managed at Polish HEls differs greatly in terms of: the time devoted to do it, the number of people engaged in the process, or the support of external entities. $34 \%$ of the responding HEls devote more than ten hours per week to use social media, $26 \%$ speak of six-ten hours, and $28 \%$ of one-five hours per week.

In $14 \%$ of cases, social media are managed/handled by more than six persons, in $44 \%$ of the respondents there are two-three persons involved in the process, and $10 \%$ have four-five such persons. $26 \%$ of the surveyed HEls (13 out of 50 ) have only one person to manage their social media platforms.

Polish HEls use social media agency services very rarely. $74 \%$ of those surveyed do not work with any external entities, $18 \%$ of them speak of such collaboration as small (operational support), and only $8 \%$ refer to it as moderate or extensive (four such responses).

Social media are considered a very important channel of advertising communication (the purchase and publishing of adverts in social media). Even $68 \%$ of the respondents admitted that their budget for social media advertising activity amounted to $0-20 \%$ of the total promotion budget, and only $6 \%$ of them allocate $21-40 \%$ of their overall budget to such a type of advertising. Interestingly enough, $22 \%$ of the respondents could not specify the exact or even approximate value of their expenses on social media advertising. Thus, it seems that social media are still not seen as an important tool for communication worthwhile investing, despite previous research concluded that social media are supportive in the enrolment process (Constantinides \& Zinck Stagno, 2011; Noel-Levitz, 2014; Wilson, 2013). 
At the same time, almost half of the respondents (46\%) expect these budgets to grow in the next one-three years, and $22 \%$ of them think they will stay at the same level. The uncertainty related to treating social media as means of advertising is proven by the fact that even $26 \%$ of the respondents have chosen 'hard to say' as their answer.

Polish HEls do not regulate broadly defined activity of their employees in social media. $62 \%$ of the respondents declared that their institution does not have any code to determine the way their employees should use social media (a so-called social media policy). In addition to that, $6 \%$ of them claimed that even though they have developed such principles, they are not known or applied in practice. Only $12 \%$ of cases (6 HEIs) have social media policies that are not only formalised but also implemented. Which means that still social media utilisation is not a professionalised action, but rather an addition to traditional marketing tools.

\section{The Scope and Purpose of the Use of Social Media at Polish Higher Education Institutions}

All of the surveyed HEls use Facebook as the primary social media communication channel (100\% responses) and consider it the most important of them (90\% responses naming FB as the most important channel). $92 \%$ of HEls use YouTube, $76 \%$ use Instagram, and $72 \%$ claim to use Twitter. What is quite interesting is that the platform considered most popular among the youngest population of Internet users - Snapchat - is used by only $38 \%$ of the surveyed HEls (19 positive responses). LinkedIn platform, which plays an important part in building the relationships with graduates, is used by $28 \mathrm{HEls}$ ( $56 \%$ positive responses). It is very rare to see the surveyed institutions use Vkontakte - with only four positive responses ( $8 \%$ of the respondents). When asked which social media platform would be most important for the pursued activity in five years, $50 \%$ of the respondents indicated Facebook, and $20 \%$ - YouTube. Snapchat was named by only four respondents (8\%). Still, for HEls Facebook seems to be the major social media platform for the contact with students. Despite of this, it still remains one of the largest platforms, its cultural importance for younger generations is declining (Sujon, Viney, \& Toker- Turnalar, 2018). It seems that HEls still lack knowledge which social media tools might be most interesting for their current and potential students. Our findings are consistent with previous findings, which concluded that HEls are increasingly more active in various social media platforms (Pharr, 2016).

The surveyed HEls were also asked about the target groups they interact with in social media. The definite number one answer was students ( $100 \%$ of such responses) and applicants (96\% of such responses). Interestingly enough, the next most often named group were graduates ( $46 \%$ responses) and academics - with only $26 \%$ responses. The published content is very rarely addressed to foreign students $(14 \% \mathrm{re}$ sponses) or to the business environment ( $4 \%$ responses). $18 \%$ of the respondents named the media as a target group that is important to consider in their institution's communication through social media. Thus, unlike Carver (2014) concluded, it seems that Polish $\mathrm{HEI}$ limit their target group to their current and potential students, in large part ignoring other important stakeholder groups (Zickar, Ron, \& Arnold, 2018).

The main purposes of using social media include: building relationships with students and graduates (78\% responses), brand building (76\% responses), and publishing news about the events taking place at a given school/university ( $72 \%$ responses). Enrolmentrelated purposes rank fourth (64\% responses). Thus, as Constantinides and Zinck Stagno 
(2011) noticed, HEls utilise social media to communicate the academic culture, atmosphere and attractions available for the students. While still, no $\mathrm{HEl}$, according to the respondents' claims, uses social media for personal branding of members of their authorities or to establish relations with the business world. Only $6 \%$ of the respondents actually mentioned supporting the personal brand of their academics as the purpose of using social media. $6 \%$ also claimed that they have specific purpose in using social media.

As for the content published via HEls' social media channels, this content is influenced to the greatest extent by institutional marketing/PR specialists $-44 \%$ responses. $34 \%$ of responses pointed to students, and $10 \%$ - to authorities. These results show that in the case of the content published in social media even in such hierarchical organisations as HEls, a lot of trust is placed in employees and students, who shape the image of these institutions in the contemporary digital setting. What is surprising is the very slight contribution of academics in the creation or initiation of such a content - only $8 \%$ of the respondents named this group in their answers.

$\mathrm{HEI}$ marketing/PR specialists are in charge not only of the published content but also of the overall presence of their institutions in social media. In $68 \%$ of cases, it is the promotion/marketing department who is responsible for the said presence. Very few responses pointed to the press office or the rector's office.

When answering an additional question about the nature of the published content, the respondents named images and links (44\%), images only (26\%), and texts and links (18\%). Video content has not been mentioned as published in HEls' social media channels, although this format is a very effective attention drawer (Heinze, Fletcher, \& Rashid, 2016). Therefore, despite HEls utilise a range of social media (Mazurek, 2018), still the format of the communication is rather traditional and limited to images, texts and links.

Interesting answers were also given to the question concerning the subjects featured in the content published in social media. The first three most common subjects included: student achievements (88\% responses), school/university events (68\% responses), and information about the school/university (60\% responses). Only $22 \%$ of this content covers findings and results of scientific research. $24 \%$ of the respondents say that the published content concerns the achievements of their institution's graduates. The decisions of a school/university authorities are virtually never announced through social media (only one positive answer).

\section{Barriers to Using Social Media at Polish Higher Education Institutions}

The study also intended to identify the main barriers to using social media at HEls in Poland. The respondents named many potential factors, all presented in the table below.

The three most significant of them are:

- lack of understanding of the significance of social media in building the education institution's brand among academic and administrative staff (even 74\% of such responses in total);

- insufficient budget ( $20 \%$ responses);

- no expert knowledge on how to implement and pursue certain activities $(20 \%$ responses).

Interestingly, similar conclusions regarding individual use of social media of academics were withdrawn from study by Noorden (2014). 
Table 3. The Respondents' Answers to the Following Question: Are There Any Barriers at Your Education Institution With Regard to Taking Advantage of Social Media? (Choose Max. 3 Most Important Ones)

\begin{tabular}{|c|c|c|c|}
\hline No. & Insitutional barriers of utilizing social media & 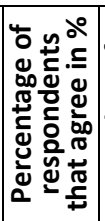 & 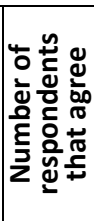 \\
\hline 1 & $\begin{array}{l}\text { Lack of understanding of the significance of social media in building the education in- } \\
\text { stitution's position on the market among the education institution's academic staff }\end{array}$ & 41.46 & 18 \\
\hline 2 & $\begin{array}{l}\text { Lack of understanding of the significance of social media in building the education insti- } \\
\text { tution's position in the market among the education institution's administrative staff }\end{array}$ & 26.83 & 12 \\
\hline 3 & No human resources (no budget to engage new specialists) & 24.39 & 10 \\
\hline 4 & No knowledge about how to implement and develop new tools and activities & 19.51 & 9 \\
\hline 5 & Resistance to change - too slow implementation of particular tools and solutions & 19.51 & 9 \\
\hline 6 & The authorities' unwillingness to develop this form of communication & 17.07 & 7 \\
\hline 7 & Poor coordination of activities pursued across social media & 14.63 & 7 \\
\hline 8 & Fear of comments - and the necessity to respond to them & 12.20 & 6 \\
\hline 9 & No content to be published & 9.76 & 5 \\
\hline 10 & No human resources despite the possibility to engage specialists & 4.88 & 2 \\
\hline 11 & Fear of losing control over the education institution's image & 4.88 & 2 \\
\hline
\end{tabular}

Source: own study.

\section{Respondents' Attitudes to Selected Aspects of Social Media}

In the study the respondents were also asked about their opinion on the social media activity of the institutions they represented. A compilation of the obtained answers is presented below.

The presented data can lead to at least several interesting conclusions. The vast majority of the respondents say that social media are an important area of marketing activity at their institutions ( $84 \%$ of such responses), which is consistent with previous studies (Constantinidez \& Znick Stagno, 2011; Carver, 2014; Noel- Levitz, 2014; Wilson, 2013). Likewise, the majority of the respondents are satisfied with the activity their institutions pursue across social media ( $82 \%$ of such responses). Most of the surveyed respondents confirm that the budgets allocated to social media depend on the outcomes of activities pursued in social media. Over $64 \%$ say that they do analyse and monitor the rate of return on social media. At the same time, the respondents are divided when it comes to the opinion on the impact of social media activity on the results of enrolment ( $44 \%$ of positive responses). It is understandable if we consider the context of the answers to another question about the key target groups which schools/universities communicate with and about the expected outcomes of social media activity.

Most respondents follow and analyse the social media activity of other HEls (68\%). However, only $38 \%$ of them declare that their institution is experienced in marketing activities carried out with the use of social media. What is interesting is that the respondents are also not sure about the fact that their online activity may reduce the overall costs of their marketing efforts - only $34 \%$ of them support this opinion. Ques- 
tions concerning the strategy and the engagement of students and graduates in the creation of the institution's brand do not offer a clear view, either. In both cases (question 12 and 13), we have an equal number of 'for' and 'against' answers, and the number of 'hard to say' answers appears to be also significant at the same time.

Table 4. Attitudes of the Surveyed Respondents to the Social Media Activity of the Institutions They Represent

\begin{tabular}{|c|c|c|c|c|c|c|c|}
\hline No. & Questions & 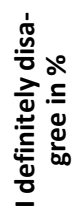 & 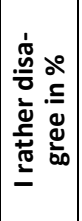 & 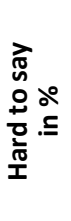 & 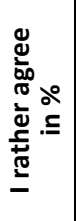 & 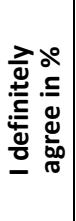 & 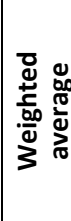 \\
\hline 1 & $\begin{array}{l}\text { Social media are an important element of marketing at } \\
\text { my education institution }\end{array}$ & 6 & 4 & 6 & 18 & 66 & 4.34 \\
\hline 2 & $\begin{array}{l}\text { I'm happy with my education institution's activity across } \\
\text { social media }\end{array}$ & 4 & 8 & 6 & 30 & 52 & 4.18 \\
\hline 3 & \begin{tabular}{|l} 
The budget on social media depends on the results \\
achieved in previous periods of social media activity
\end{tabular} & 2 & 2 & 14 & 44 & 38 & 4.14 \\
\hline 4 & $\begin{array}{l}\text { We analyse the social media activity of other education } \\
\text { institutions on an ongoing basis }\end{array}$ & 6 & 8 & 18 & 36 & 32 & 3.8 \\
\hline 5 & $\begin{array}{l}\text { The knowledge and information gained from social media } \\
\text { are used by the education institution's decision-makers }\end{array}$ & 4 & 12 & 22 & 34 & 28 & 3.7 \\
\hline 6 & We measure the ROI in social media & 6 & 10 & 20 & 40 & 24 & 3.66 \\
\hline 7 & $\begin{array}{l}\text { The education institution authorities get involved in so- } \\
\text { cial media activities }\end{array}$ & 10 & 20 & 20 & 28 & 22 & 3.32 \\
\hline 8 & $\begin{array}{l}\text { The education institution authorities understand the signifi- } \\
\text { cance of social media for the education institution }\end{array}$ & 6 & 12 & 44 & 22 & 16 & 3.3 \\
\hline 9 & $\begin{array}{l}\text { The education institution is experienced in social media } \\
\text { activities }\end{array}$ & 16 & 16 & 30 & 18 & 20 & 3.1 \\
\hline 10 & $\begin{array}{l}\text { The education institution's social media activities have an } \\
\text { impact on the enrolment at the education institution }\end{array}$ & 24 & 14 & 18 & 20 & 24 & 3.06 \\
\hline 11 & $\begin{array}{l}\text { Our social media activities have reduced the costs of mar- } \\
\text { keting activities }\end{array}$ & 16 & 12 & 38 & 20 & 14 & 3.04 \\
\hline 12 & \begin{tabular}{|l|} 
The education institution's social media activities are \\
based on a coherent, well-thought-out strategy
\end{tabular} & 18 & 18 & 24 & 26 & 14 & 3 \\
\hline 13 & $\begin{array}{l}\text { We carry out activities that encourage our students and } \\
\text { alumni to build and promote our brand across social media }\end{array}$ & 16 & 26 & 22 & 22 & 14 & 2.92 \\
\hline 14 & The rector and vice-rectors are present in social media & 16 & 32 & 26 & 20 & 6 & 2.68 \\
\hline
\end{tabular}

Source: own study.

There are interesting insights in the answers to questions related to the attitudes of $\mathrm{HEI}$ authorities to social media marketing activity. First of all, the respondents say that the authorities of their institutions are absent from social media ( $48 \%$ of 'no' or 'definitely no' answers - question 14). At the same time, $50 \%$ of the respondents (question 7) say that the authorities of their institutions do get involved in the social media activity, which may mean that their engagement does not equal a willingness or necessity to promote oneself in social media. This somewhat distorts the answer to the question about the significance of social media for the education institution as perceived by the authorities of this institution (question 8 ). In the case of this question, we have a record- 
breaking number of 'hard to say' answers, with $44 \%$ of the respondents choosing this answer. Finally, according to even $62 \%$ of the respondents, school/university authorities use the knowledge and information coming from social media to manage their institutions (question 5). The issue of the attitude of $\mathrm{HEI}$ authorities in Poland to social media certainly requires more in-depth analyses and additional research.

\section{CONCLUSIONS}

Social media are an extremely significant communication channel in the world of today, determining also changes in the way HEls interact with their stakeholders (Carver, 2014).

The potential of social media should be taken advantage of especially in the area of marketing communications, including enrolment activities, communication with students, or the broadly defined brand building (Pharr, 2016). In order to find out how HEls in Poland benefit from and utilise social media, we sent surveys to 90 marketing departments of the $\mathrm{HEIs}$. The current study concerning the use of social media conducted in a group of representatives of 50 Polish HEls have made it possible to draw at least several interesting conclusions. First, social media are considered 'youth' media, which is manifested both in the default target audience intended to be reached through these media (students, applicants) and the content published in these media (student achievements). Interestingly enough, in the case of Polish HEls, social media are not utilised to promote the conducted science and research or schools and universities as thriving academic centres, as it was visible in other studies (Carver, 2014; Pharr, 2016). At the same time, according to the respondents taking part in the survey, the biggest obstacle to a more advanced adoption of social media in HEls is the attitude of academics to social media.

As for the field of management, it is important to bear in mind that many Polish HEls are quite experienced in the matter in question, taking advantage of contemporary means of communication for at least three years - as many as 45 out of 50 surveyed institutions. Over $60 \%$ of the surveyed institutions spend more than five hours per week using their social media platforms actively. A characteristic feature is that HEls in Poland carry out their social media activities alone, with external entities providing them with occasional support - at an operational level if any. The question of whether it results from an insufficient amount of resources, from a lack of need for such support, or from consciously treating these activities as strategic - meaning carrying them out with the use of internal unique resources - remains still unanswered and requires further research. Working with social media at Polish HEls is usually teamwork - only about $25 \%$ of the surveyed institutions have it carried out by one person, and the entities in charge of this sphere are mainly marketing departments.

Polish HEls have not yet considered social media a key advertising communication channel - about $70 \%$ of the surveyed institutions allot approximately $0-20 \%$ of their promotion budget, proving how little advantage they take of social media for advertising purposes.

HEls in Poland implement social media policies to a very limited extent. It is another research element worth being analysed in a more in-depth manner. Does it come from unawareness of the significance of such principles, or - quite the opposite - does it come from an assumption that employees do not need any special rules of communication via social media because they are fully aware of the risks inherent to such communication?

The value an organisation gains from utilising social media is inseparably determined by the specific platform taken advantage of. And therefore, when it comes to the scope 
and the purpose of the utilisation of social media, it is necessary to stress that Polish HEls tend to consider Facebook a social media platform of the biggest significance - both now and in the future, despite its importance among students is diminishing (Sujon, Viney, \& Toker-Turnalar, 2018). Snapchat is rather disregarded, despite the fact that it is becoming even more popular than Facebook among those who are soon going to be applying for admission to higher schools and universities. The most important target audiences of social media activity are: students, applicants, and graduates. Polish HEls tend to address their communication to academic and business environments rarely. The purposes of utilising social media include mainly: relationship building, brand building, information, and enrolment activities. The published content is created and managed by marketing specialists. It is created by students or representatives of school/university authorities to a limited extent. This content is usually visual and static (images), video formats were not mentioned, which is also interesting because video is actually the most engaging format as observed among social media users. The content published most often includes: student achievements, school/university news, and major events.

The main barriers to a more comprehensive adoption of social media at Polish HEls are: lack of understanding of the significance of social media in building the education institution's brand among academic and administrative staff. Next on the list are the issue of financial resources (budget) and the sense of having not enough expert knowledge to carry out and manage these activities in a comprehensive way.

An interesting observation regarding the respondents' answers is the undecidedness concerning the impact of school/university authorities on social media activities and the scope of their own activity in the digital social setting, which is contradictory to the study conducted by van Noorden (2014), who found that academics are rather frequent users of social media, especially those dedicated to scholarly communication. The obtained responses offer a rather vague view of the situation. The respondents emphasize the significance of social media in the entirety of their institutions' marketing activities, and admit that they are very satisfied with the activities carried out.

To summarise, we can say that although Polish HEls take advantage of social media keenly and extensively, they still view them mainly as the space for marketing operations, used to communicate with young people through 'youth' content. Social media are not used to promote schools and universities as serious academic/research centres, nor are they used to disseminate research findings or promote academics. They are not used by school and university authorities, researchers or teachers to build their personal brands either. It seems that HEls in Poland still have to develop in this manner to use social media tools more comprehensively for communication not only with potential students but as well as with other stakeholders. Our main recommendation for practice is that HEls in Poland should utilise social media in a more comprehensive manner on the one hand, while on the other hand they should develop a strategy on how to use social media effectively to achieve goals. Polish HEI still lack a consistent strategy on how to utilise social media for communication. Similarly, HEls need to adjust the channels of communicating with their stakeholders, whereas alumni and graduate students still can be researched with Facebook, younger generation of potential students are more likely to be present on other social media platforms (Sujon, Viney, \& Toker- Turnalar, 2018). Our study revealed how much there is still to be done by HEls in Poland. 
The major limitation of the study is the small sample, we were able to survey only $50 \mathrm{HEls}$. Moreover, the survey was conducted on respondents with differing background and marketing position within the institution, which could influence the differences in answers between the HEls.

It seems essential to repeat the research presented in this article and make it more in-depth in order to grasp the dynamics of the development of the utilisation of social media by Polish HEls, and to juxtapose the findings with the results obtained from surveys filled in by students and academic staff members. It is also possible - and reasonable - to conduct comparative studies in other markets.

\section{REFERENCES}

Bartosik-Purgat, M. (2018). International Contexts of Social Media and e-WoM Communication in the Customer Decision-Making Process. Journal of Management and Business Administration. Central Europe, 26(2), 16-33.

Bennett, S., \& Maton, K. (2010). Beyond the 'digital natives' debate: towards a more nuanced understanding of students' technology experiences. Journal of Computer Assisted Learning, 26(5), 321-331. https://doi.org/10.1111/j.1365-2729.2010.00360.x

Blackshaw, P., \& Nazzaro, W. (2004). Consumer-Generated Media (CGM) 101: Word-of-mouth in the age of the Web-fortified consumer. Retrieved on June 22, 2018 from http://www.nielsenbuzzmetrics.com/whitepapers

Caraher, K., \& Braselman, M. (2010). The 2010 21st-Century Campus Report: Campus 2.0. CDW Government LLC. Retrieved on June 10, 2018 from http://webobjects.cdw.com/webobjects/me$\mathrm{dia} /$ pdf/newsroom/CDWG-21st-Century-Campus-Report-0710.pdf

Carver, R.B. (2014). Public communication from research institutes: Is it science communication or public relations?. Journal of Science Communication, 13, 1-4. https://doi.org/10.22323/2.13030301

Chaffey, D., \& Ellis- Chadwick, F. (2012). Digital marketing: Strategy, implementation and practice. Fifth edition. London, UK: Pearson.

Constantinides, E., \& Zinck Stagno, M.C. (2011). Potential of social media as instruments of higher education marketing: A segmentation study. Journal of Marketing for Higher Education, 21, 724. https://doi.org/10.1080/08841241.2011.573593

Constantinides, E., \& Zinck Stagno, M.C. (2012). Higher Education Marketing: A Study on the Impact of Social Media on Study Selection and University Choice. International Journal of Technology and Educational Marketing, 2(1), 41-58. https://doi.org/10.4018/ijtem.2012010104

Heinze, A., Fletcher, G., \& Rashid, T. (2016). Digital and social media marketing. London, UK: Routledge.

Dumford, A., \& Miller, A. (2018). Online learning in higher education: exploring advantages and disadvantages for engagement. Journal of Computing in Higher Education, 3(30), 452-465. https://doi.org/10.1007/s12528-018-9179-z

Himelboim, I., Golan, G.J., Moon, B.B., \& Suto, R.J. (2014). A social networks approach to public relations on Twitter: Social mediators and mediated public relations. Journal of Public Relations Research, 26, 359-379. https://doi.org/10.1080/1062726X.2014.908724

Hrastinski, S., \& Aghaee, N. (2012). How are campus students using social media to support their studies? An explorative interview study. Education and Information Technologies, 17(4), 451464. https://doi.org/10.1007/s10639-011-9169-5 
Jones, C., \& Czerniewicz, L. (2010). Describing or debunking? The Net generation and digital natives. Journal of Computer Assisted Learning, 26(5), 317-320. https://doi.org/10.1111/j.13652729.2010.00379.x

Janoskova, K., \& Kliestikova, J. (2018). Analysis of the impact of selected determinants on brand value. Journal of International Studies, 11(1), 152-162. https://doi.org/10.14254/2071-8330.2018/11-1/11

Jones, C., Ramanau, R., Cross, S., \& Healing, G. (2010). Net generation or digital natives: Is there a distinct new generation entering university?. Computers \& Education, 54(3), 722-732. https://doi.org/10.1016/j.compedu.2009.09.022

Kajanová, H., Sedláček, M., \& Soósová, V. (2017), Attitudes of Young People to Job Searching through Social Media: Case of Slovakia. Economics and Sociology, 10(1), 152-168. https://doi.org/10.14254/2071-789X.2017/10-1/11

Kaplan, A.M., \& Haenlein, M. (2010). Users of the World, Unite! The Challenges and Opportunities of Social Media. Business Horizons, 53(1), 61. https://doi.org/10.1016/j.bushor.2009.09.003

Kaplan, A.M., \& Mazurek, G. (2018). Social Media: State of the Art and Research Agenda. In B. Mierzejewska, J. Jung, \& A. Albarran (Eds.,), Handbook of Media Management and Economics (pp. 273-286). London: Routledge.

Kelleher, T., \& Sweetser, K. (2012). Social media adoption among university communicators. Journal of Public Relations Research, 24, 105-122. https://doi.org/10.1080/1062726X.2012.626130

Lazányi, K., Čepel, M., \& Bilan, S. (2017). Comparison of Trust and Social Relations among Students in Russian and Hungarian Higher Education. Economics and Sociology, 10(4), 162-174. https://doi.org/10.14254/2071-789X.2017/10-4/13

Mącik, R., Mazurek, G., \& Mącik, D. (2012). Channel characteristics influence on physical vs. virtual channel choice for information search and purchase - the case of Polish young customers. International Journal of Cyber Society and Education, 5(1), 35-54.

Mazurek, G. (2008). Blogi i wirtualne społeczności konsumenckie (pp. 111-119). Kraków: Wolters Kluwer Polska.

Mazurek, G. (2008). Web 2.0 implications on marketing. A paper presented at the Section 3 conference. Management Development: Ways, Means and Instruments - Marketing development.

Mazurek, G. (2014). Network value creation though marketing. Management and Business Administration. Central Europe, 22(4), 70-77. https://doi.org/10.7206/mba.ce.2084-3356.120

Mazurek, G. (2016). Ewolucja wykorzystania mediów społecznościowych w marketingu. Nierówności Społeczne a Wzrost Gospodarczy, 45, 15-23. https://doi.org/10.15584/nsawg.2016.1.2

Mazurek, G. (2018). E-marketing. Planowanie - Narzędzia - Praktyka. Warsaw: Poltext.

Mazurek, G. (2014). Virtual marketing. In A. Ghorbani (Ed.), Marketing in Cyber Era-Strategies and Emerging Trends (pp. 16-36). IGI Global, Hershey, USA. https://doi.org/10.4018/978-1-4666-4864-7

McAlexander, J.H., Koenig, H.F., \& Schouten J.W. (2006). Building relationships of brand community in higher education: A strategic framework for university advancement. International Journal of Educational Advancement, 6(2), 107-118. https://doi.org/10.1057/palgrave.ijea.2150015

Nevzat, R., Amca, Y., Tanova, C., \& Amca, H. (2016). Role of social media community in strengthening trust and loyalty for a university. Computers in Human Behavior, 65, 550-559. https://doi.org/10.1016/j.chb.2016.09.018

Noel-Levitz, R. (2014). E-Expectations: Graduate Edition: Advanced Degrees of E-Recruitment. Retrieved on June 10, 2018 from https://www.ruffalonl.com/documents/shared/Papers_and_Research/2007/E-Expectations\%20Graduate\%20Edition_0107.pdf

Noorden van, R. (2016). Scientists and the social network. Nature. 512(1), https://doi.org/10.1038/512126a 
Pharr, J. (2016). University Branding 2.0-Harnessing the Power of Social Media for Open-Source Branding and Brand Co-Creation of Colleges and Universities. Proceedings of the Atlantic Marketing Association. Retrieved on July 12, 2018 from https://digitalcommons.kennesaw.edu/cgi/viewcontent.cgi?article=1148\&context=ama_pr oceedings, 11

Rutter, R., Roper, S., \& Lettice, F. (2017). Social media interaction, the university brand and recruitment performance. Journal of Business Research, 69, 3096-3104. https://doi.org/10.1016/j.jbusres.2016.01.025

Skulme, R., \& Praude, V. (2016). Social media evaluation metrics. Oeconomia Copernicana, 7(1), 131142. https://doi.org/10.12775/OeC.2016.009.

Sujon, Z., Viney, L., \& Toker-Turnalar, E. (2018). Domesticating Facebook: the shift from compulsive connection to personal service platform. Social Media + Society. 4(4), https://doi.org/10.1177/2056305118803895

Sułkowski, Ł. (2016). Accountability of University: Transition of Public Higher Education. Entrepreneurial Business and Economics Review, 4(1), 9-22. https://doi.org/10.15678/eber.2016.040102

Smilansky, S. (2017). Experiential marketing: A practical guide to interactive brand experiences. Kogan Page Publishers, 19.

Wilson, C.D. (2013). Making connections: Higher education meets social media. The Magazine of Higher Learning, 45(4), 51-57. https://doi.org/10.1080/00091383.2013.806201

Zickar, M., Ron, T., \& Arnold, C. (2018). Using Facebook pages to connect with students, faculty, alumni and friends: an empirical analysis. Teaching of Psychology. 45(4), 358-362. https://doi.org/10.1177/0098628318796923 


\section{Authors}

\section{Contribution share of authors is equal and amounted to $33,3 \%$ each of them.}

\section{Grzegorz Mazurek}

Associate Professor of Marketing and Associate Dean for International Relations at Kozminski University. He is responsible for the development and execution of internationalisation strategy of Kozminski University. In his research he specialises in digital transformation - the new technologies impact on management and marketing. Grzegorz Mazurek authored four books: 'Digital Transformation - marketing perspective', 'Virtualization of marketing and its impact on network value creation', 'Blogs and virtual communities in marketing' and 'Promotion on the Internet'. His scientific articles can be found, among others, in: Economic and Business Review, Management and Business Administration Central Europe, Contemporary Management Research Journal, International Journal of Cyber Society and Education.

Correspondence to: Prof. Grzegorz Mazurek, PhD, Koźmiński University, Chair of Marketing, ul. Jagiellońska 57/59, 03-301 Warsaw, Poland e-mail: gmazurek@kozminski.edu.pl

ORCID (ㄱ) http://orcid.org/0000-0002-0047-6944

\section{Paweł Korzyński}

Assistant Professor of Management at Koźmiński University, he also has the status of 'visiting scholar' at INSEAD Business School. In his research he specialises in such areas as: leadership in digital age, social media usage and personal branding, management in digital transformation. $\mathrm{He}$ authored book entitled: 'Leadership in digital age', he also authored many articles in such journals as Business Horizons and Management Decision.

Correspondence to: Paweł Korzyński, PhD, Koźmiński University, Chair of Management, Jagiellońska 57/59, 03-301 Warsaw, Poland, e-mail: pkorzynski@kozminski.edu.pl ORCID (1) http://orcid.org/0000-0002-6457-4965

\section{Anna Górska}

PhD candidate at Koźmiński University and Fulbright scholar winner. She works as an assistant lecturer and researcher in Marketing Department at Koźmiński University. Her areas of interest include: personal branding, social media marketing and marketing in Higher Education Institutions. She has already published as author or co-author of several articles and chapters in renowned journals (e.g. Springer, MBACE, AAAJ).

Correspondence to: Anna Górska, PhD candidate, Koźmiński University, Chair of Marketing, Jagiellońska 57/59, 03-301 Warsaw, Poland, e-mail: amg@kozminski.edu.pl

ORCID (1) http://orcid.org/0000-0003-3406-5454

\section{Copyright and License}

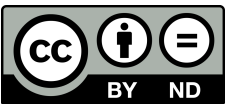

This article is published under the terms of the Creative Commons

Attribution - NoDerivs (CC BY-ND 4.0) License

http://creativecommons.org/licenses/by-nd/4.0/

\section{Published by the Centre for Strategic and International Entrepreneurship - Krakow, Poland}


